\title{
Expression of adrenomedullin by human granulosa lutein cells and its effect on progesterone production
}

Toshitake Moriyama, Tetsuo Otani and Takeshi Maruo

Department of Obstetrics and Gynecology, Kobe University School of Medicine, Kobe, 650-0017, Japan

(Correspondence should be addressed to T Maruo, Department of Obstetrics and Gynecology, Kobe University School of Medicine, 7-5-1 Kusunoki-cho, Chuo-ku, Kobe 650-0017, Japan; Fax: +81-78-3826019)

\begin{abstract}
Objective: Adrenomedullin (AM) has diverse functions and is expressed in a variety of tissues. This study was conducted to investigate the expression of AM in the human ovary and its effect on progesterone production by human granulosa lutein cells.

Design and Methods: Follicular fluid and blood samples were obtained at the time of oocyte retrieval from patients undergoing in vitro-fertilization cycles. Concentrations of AM in follicular fluid and plasma were measured by RIA. Granulosa cells were isolated from follicular fluid and expression of AM mRNA was examined by RT-PCR. Granulosa lutein cells were cultured in vitro and secretion of AM by those cells was determined by immunoprecipitation followed by PAGE. Immunohistochemical staining with human ovaries was carried out, using a specific antibody to AM. Furthermore, the effect of AM on progesterone production by cultured granulosa lutein cells was studied.

Results: Concentrations of AM in follicular fluid collected just before ovulation were significantly higher than those in the plasma $(P<0.01)$. AM mRNA was expressed in granulosa cells at the preovulatory stage. Cultured granulosa lutein cells secreted immunoreactive AM. With immunohistochemical staining, it was revealed that AM was most abundantly expressed in granulosa lutein cells at the midluteal phase. No appreciable staining for AM was observed in granulosa cells in primordial and preantral follicles, whereas immunolocalization of AM was noted in granulosa cells of dominant follicles although it was not as prominent as in granulosa lutein cells at the midluteal phase. Furthermore, addition of AM to cultured granulosa lutein cells augmented progesterone secretion in a dose-dependent manner.

Conclusions: These results suggest that AM is transcribed and secreted in human granulosa lutein cells as a local factor to enhance progesterone production by those cells.
\end{abstract}

European Journal of Endocrinology 142 671-676

\section{Introduction}

Adrenomedullin (AM) is a multifunctional peptide first isolated from human pheochromocytoma by monitoring the elevating activity of the platelet cyclic adenosine monophosphate (cAMP) (1). Its gene, consisting of 4 exons is located on the 11 th chromosome (2). The precursor (proadrenomedullin) for human AM is 185 amino acids in length (3) and post-translational processing of this peptide generates two bioactive peptides, AM and proadrenomedullin N-terminal peptide (PAMP) (4-6). While the two peptides share no structural similarity, both exhibit strong vasodilative function $(3,5)$. AM is expressed in a variety of tissues and has diverse physiological functions $(7-11)$. The most well known function of $\mathrm{AM}$ is as a strong vasodilator exhibiting long-lasting hypotensive effects (12). It has been reported that AM may also play an important role in the physiology of pregnancy (13-15).
In reproductive physiology, the mechanisms controlling follicular growth and regression are not fully established, although it is suggested that various growth factors and cytokines take part in the growth and luteinization of ovarian follicles. In this study, we first investigated the possibility of AM production in the human granulosa lutein cells and then examined its biological function in the human ovary. These results indicate a potential role for $\mathrm{AM}$ in regulating the maturation of human ovarian follicles.

\section{Materials and methods}

\section{Materials}

Both follicular fluid samples, including granulosa cells, from the leading follicle, and blood samples were obtained at the time of oocyte retrieval from 
patients undergoing in-vitro fertilization (IVF) cycles. Patients were given a daily human menopausal gonadotropin (hMG) injection of $225 \mathrm{IU}$ (Humegon, Organon Japan, Tokyo, Japan) until at least three follicles $\geq 16 \mathrm{~mm}$ diameter were shown to be present by vaginal ultrasonographic scan, at which time $5000 \mathrm{IU}$ human chorionic gonadotropin (hCG) were injected. Oocyte retrieval was carried out $36 \mathrm{~h}$ after hCG injection.

Ovarian tissues were obtained from patients having regular menstrual cycles who underwent hysterectomy with bilateral salpingo-oophorectomy for early cervical cancer.

Informed consent for the use of the patient's samples was obtained.

\section{AM in plasma and follicular fluid}

The follicular fluid and blood samples obtained were quickly mixed with EDTA ( $1 \mathrm{mg} / \mathrm{ml}$ of sample) and aprotinin $(500 \mathrm{kIU} / \mathrm{ml}$ of sample), centrifuged for $10 \mathrm{~min}$ and the supernatants were stored at $-80^{\circ} \mathrm{C}$. Sep Pak C18 cartridges were prewashed sequentially with $5 \mathrm{ml}$ each of chloroform, methanol, $50 \%$ acetonitrile containing $0.1 \%$ trifluoroacetic acid (TFA), $0.1 \%$ TFA and saline solution. Thawed samples were loaded on the Sep Pak C18 cartridges, then the cartridges were washed three times with $3 \mathrm{ml}$ 1\% TFA in distilled water and AM bound to the cartridges was extracted with $3 \mathrm{ml}$ $60 \%$ acetonitrile in 1\% TFA in distilled water. RIA for AM was performed using a radioimmunoassay kit purchased from Peninsula Laboratories, Inc. (Belmont, CA, USA).

\section{Reverse transcription (RT)-PCR detection of AM mRNA in human granulosa cells}

Total RNA was extracted from human granulosa cells, obtained at the time of oocyte retrieval, by the guanidine isothianate method. A set of primers that recognizes the most conserved regions of the AM gene was used for RT-PCR (Table 1). The expected size of PCR product for AM was $410 \mathrm{bp}$. Reverse transcription was carried out with murine leukemia virus reverse transcriptase (Perkin Elmer, Norwalk, CT, USA) for $60 \mathrm{~min}$ at $42^{\circ} \mathrm{C}$ using $1 \mu \mathrm{g}$ total RNA, and then the reaction was heat-inactivated for $5 \mathrm{~min}$ at $99^{\circ} \mathrm{C}$ and quick-chilled for $5 \mathrm{~min}$ at $5^{\circ} \mathrm{C}$. Thermal cycle profiles used in this study were as follows: (i) denaturing for $60 \mathrm{~s}$ at $95^{\circ} \mathrm{C}$, (ii) annealing primers for $60 \mathrm{~s}$ at $55^{\circ} \mathrm{C}$, and (iii) extending the primers for $60 \mathrm{~s}$ at $72{ }^{\circ} \mathrm{C}$. The PCR was repeated for 30 cycles. The PCR product was electrophoresed in $2 \%$ agarose gel in TBE buffer $(45 \mathrm{mM}$ Trisborate pH 7.5 ImM EDTA). The nucleotide sequence of the PCR product was determined by the dideoxy method.

\section{Immunoprecipitation of AM secreted by cultured human granulosa lutein cells}

Granulosa cells obtained at the time of oocyte retrieval were treated with trypsin EDTA (Gibco-BRL, Gaithersburg, MD, USA). Cells $\left(10^{5}\right)$ were seeded onto Falcon multiwell plates and incubated overnight in RPMI-1640 containing $10 \%$ fetal calf serum at $37^{\circ} \mathrm{C}$ under $5 \% \mathrm{CO}_{2}$ atmosphere. After $24 \mathrm{~h}$ preincubation, the cells were washed with PBS and were cultured with RPMI-1640 containing ${ }^{35} \mathrm{~S}$-cysteine- ${ }^{35} \mathrm{~S}$-methionine (Amersham Ltd, Amersham, Bucks, UK). After $6 \mathrm{~h}$, the medium was collected and extracted with Sep Pak C14 columns. The extract was incubated with anti-human AM antibody at room temperature for $12 \mathrm{~h}$. The antigen-antibody complex was absorbed with Pansorbin (Calbiochem, La Jolla, CA, USA) and loaded onto SDS-PAGE. After electrophoresis, the gels were dried and autoradiographed.

\section{Immunohistochemical staining for $A M$ in ovarian tissues}

Ovarian tissues were fixed in $4 \%$ buffered neutral formalin. Sections of $4 \mu \mathrm{m}$ were prepared for immunohistochemical staining which was performed by the avidin/biotin immunoperoxidase method using a polyvalent immunoperoxidase kit (Omnitag, Lipshaw, MI, USA). The primary antibody used was a rabbit polyclonal antibody against human AM (Peninsula Laboratories, Inc.). Avidin-horseradish peroxidase was used in the second incubation. Chromogenic reaction was developed with a freshly prepared solution of tetrahydrochloride diaminobenzidine and hydrogen peroxidase. The sections were counterstained with Harris hematoxylin. The following control procedures were undertaken to assure the specificity of the immunological reactions. The control section was subjected to the same immunoperoxidase method, except that the primary antibody to AM was replaced by non-immune rabbit serum at the same dilution as the specific primary antibody. In the control, no positive staining was observed.

Table 1 Sequences of the oligonucleotides synthesized for RT-PCR detection of AM mRNA in human granulosa cells.

\begin{tabular}{lc}
\hline Adrenomedullin & Sequence \\
\hline Sense (AM 250-270) & 5'-AAG-AAG-TGG-AAT-AAG-TGG-GCT-3' \\
Antisense (AM 640-660) & 5'-TGG-CTT-AGA-AGA-CAC-CAG-AGT-3'
\end{tabular}




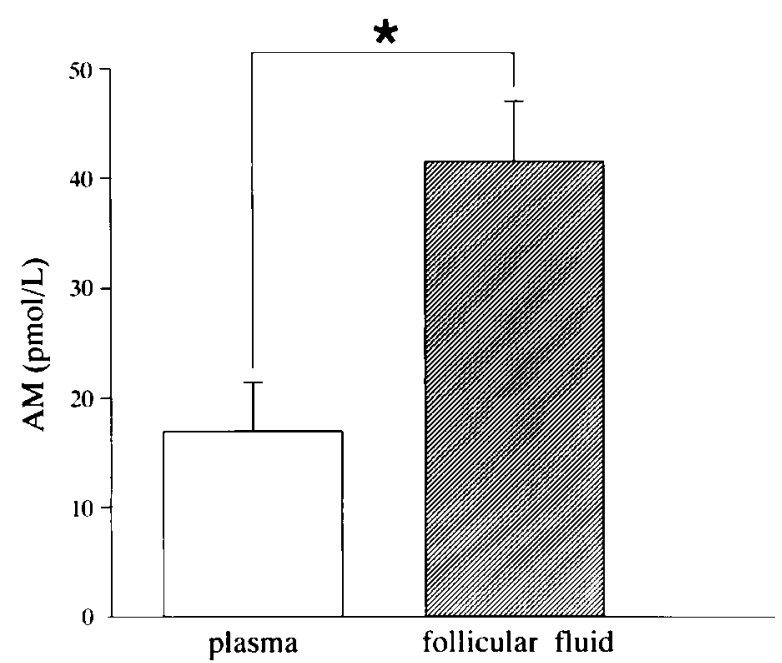

Figure 1 Concentrations of AM in follicular fluid of preovulatory follicles and plasma obtained at the same time as oocyte retrieval from 15 patients. The concentrations of AM in the follicular fluid were significantly higher than those in the plasma. Results are mean \pm S.E. ${ }^{*} P<0.01$.

\section{Progesterone measurement}

After $24 \mathrm{~h}$ pre-incubation of human granulosa lutein cells, graded concentrations of AM were added. The media were retrieved after the subsequent incubation for $16 \mathrm{~h}$ and progesterone in the media was measured with a progesterone RIA kit purchased from Nippon DPC, Inc. (Tokyo, Japan).

\section{Statistical analysis}

Statistical significance was evaluated using Student's $t$-test for paired comparison. Differences with $P$ values $<0.05$ were considered significant.

\section{Results}

\section{AM concentrations in follicular fluid and plasma}

Although plasma and follicular fluid were collected from patients at the same time, the time of oocyte retrieval, AM concentrations in follicular fluid were significantly higher $(P<0.01)$ than those in plasma in 15 patients (Fig. 1).

\section{AM mRNA expression in granulosa cells}

When RT-PCR with specific primers for AM was performed using RNA extracted from granulosa cells obtained at the time of oocyte retrieval, a band of $410 \mathrm{bp}$ in size was observed (Fig. 2). Dideoxy sequencing of this band revealed that it was consistent with the AM mRNA nucleotide sequence previously published (2). When reverse transcriptase was omitted, no band was apparent.

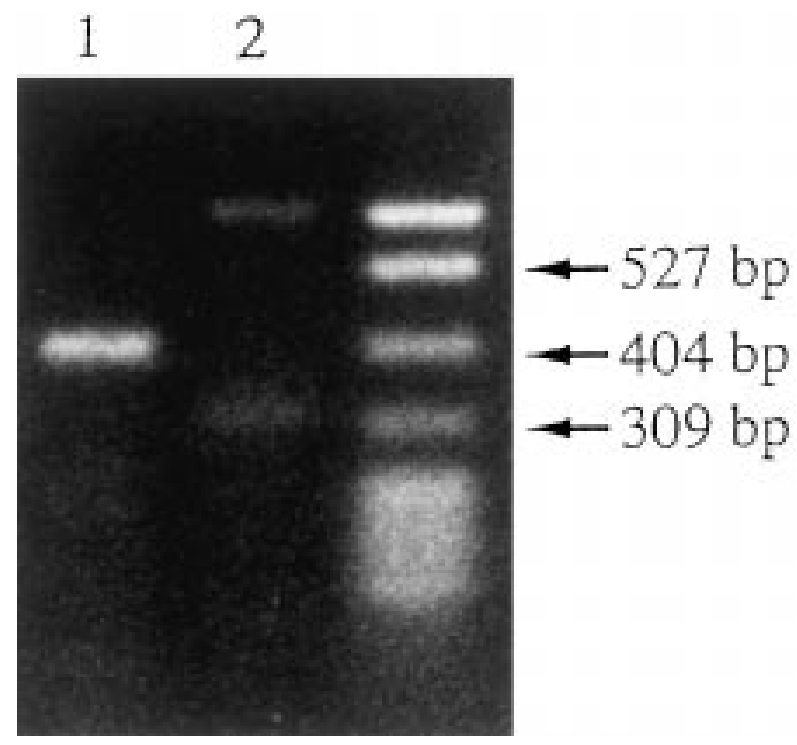

Figure 2 Expression of AM mRNA in human granulosa cells. AM mRNA was reverse transcribed and subjected to 30 cycles of PCR amplification. A band of $410 \mathrm{bp}$ in size was observed (lane 1). When reverse transcriptase was omitted (negative control: lane 2), no band was found.

\section{AM production by cultured granulosa Iutein cells}

Cultured granulosa lutein cells were metabolically labeled with ${ }^{35} \mathrm{~S}$-cysteine- ${ }^{35} \mathrm{~S}$-methionine and the proteins secreted into the media were immunoprecipitated with specific antibody. A radioactive band of $6 \mathrm{kDa}$ which corresponds to AM peptide was demonstrated (Fig. 3).

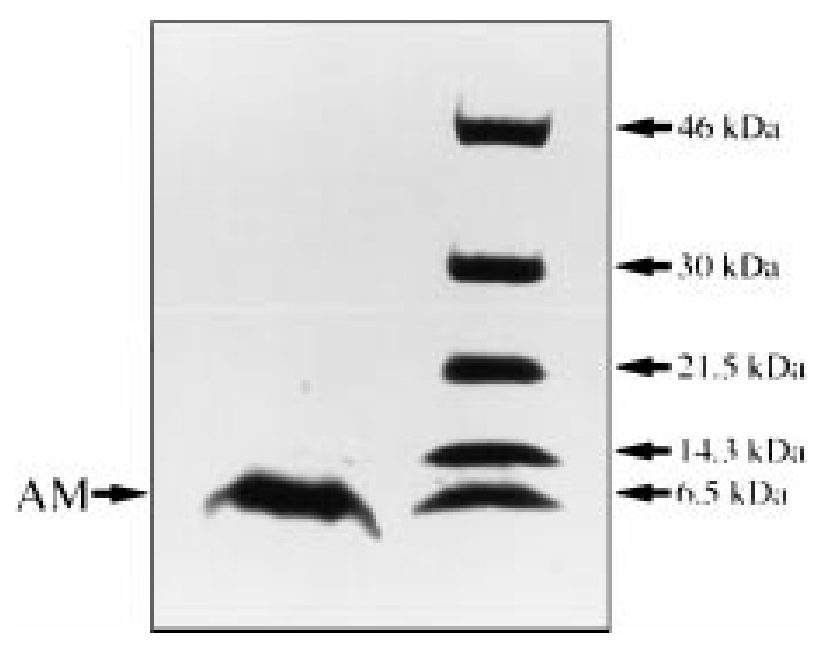

Figure 3 Production of AM peptide by cultured human granulosa lutein cells. Granulosa lutein cells obtained at the time of oocyte retrieval were cultured in vitro in the presence of ${ }^{35} \mathrm{~S}$-cysteine${ }^{35} \mathrm{~S}$-methionine for $6 \mathrm{~h}$. Then, proteins secreted into the media were immunoprecipitated with a specific antibody to AM. A ${ }^{35}$ S-labeled band of $6 \mathrm{kDa}$ corresponding to AM peptide was apparent on SDSPAGE electrophoresis. 


\section{Immunohistochemical localization of $A M$ in the human ovary}

AM was most abundantly expressed in the granulosa lutein cells at the midluteal phase. Moderate immunostaining for AM was observed in the granulosa lutein cells at the late luteal phase. In dominant follicles, immunostaining for AM was observed in the granulosa cells but it was not as prominent as in the granulosa lutein cells at the midluteal phase. No immunostaining
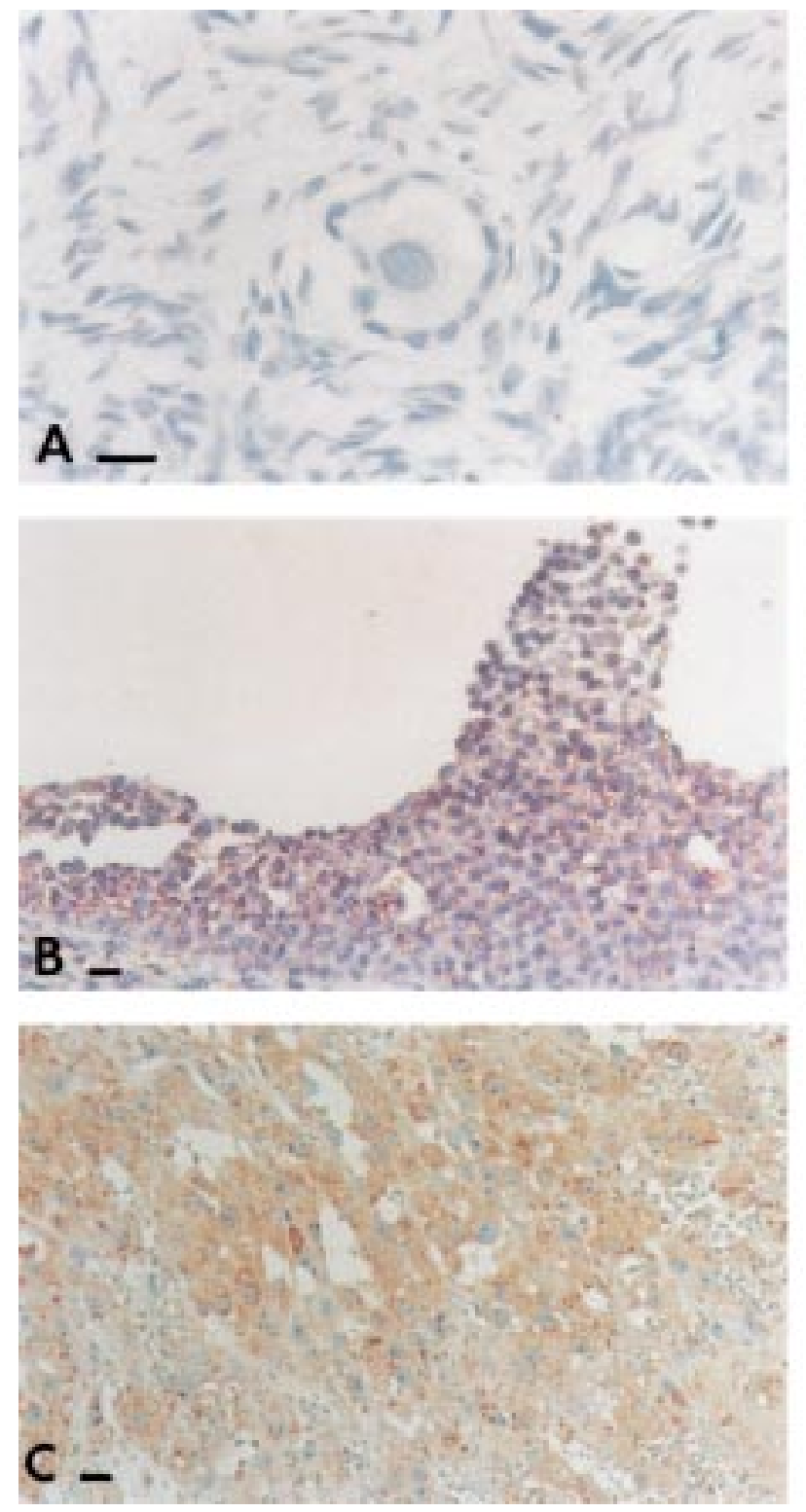

for AM was observed in the granulosa cells of primordial and preantral follicles (Fig. 4).

\section{Effect of AM on progesterone production by cultured granulosa lutein cells}

When AM at concentrations of $10^{-10}$ to $10^{-6} \mathrm{~mol} / \mathrm{l}$ was added to the medium of granulosa lutein cells cultured in vitro, the amount of progesterone secreted by cultured
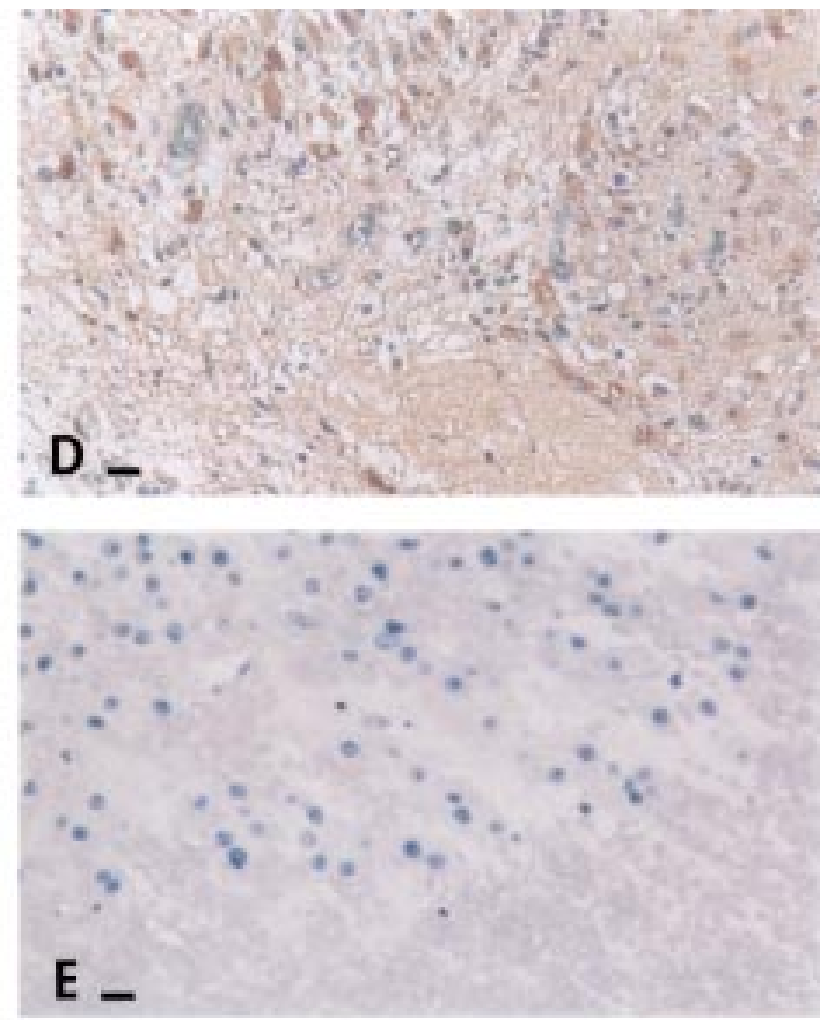

Figure 4 Immunohistochemical localization of AM in primordial follicle (A), dominant follicle $(B)$ and corpus luteum at the midluteal phase (C) and at the late luteal phase (D) within the human ovary. Immunohistochemical staining for AM showed that AM was most abundant in granulosa lutein cells in the corpus luteum at the midluteal phase, less abundant in granulosa cells in dominant follicles, and least abundant in granulosa cells in primordial follicles in the human ovary. Replacement of the primary antibody with nonimmune rabbit serum showed a lack of positive staining of granulosa lutein cells at the midluteal phase $(\mathrm{E})$. Bars represent $10 \mu \mathrm{m}$. (Original magnification $A, \times 400 ; B, C, D$ and $E, \times 200$.) 


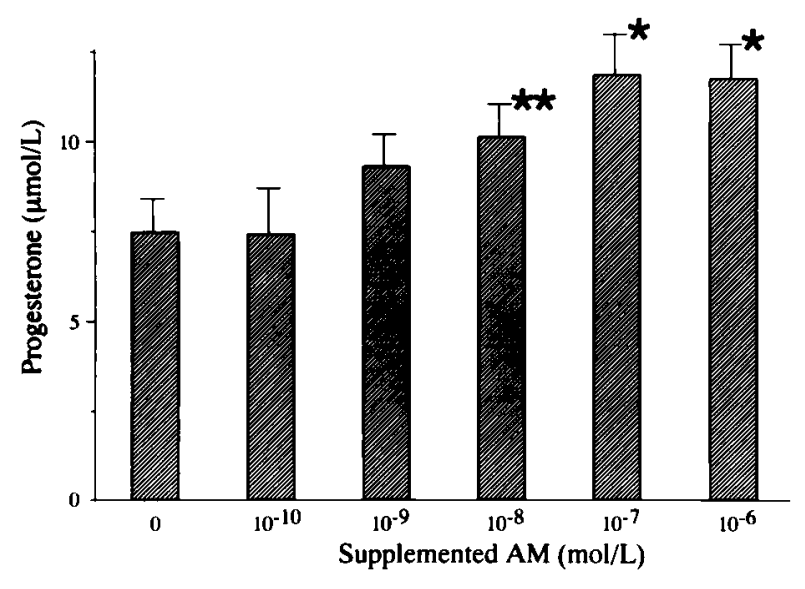

Figure 5 Effect of AM on progesterone production by cultured granulosa lutein cells. Granulosa lutein cells were incubated for $16 \mathrm{~h}$ in the presence or absence of various concentrations of AM. The progesterone concentrations in the medium were assayed by RIA. The experiments were carried out in five replicates. Results are means \pm S.E. ${ }^{\star} P<0.01,{ }^{\star \star} P<0.05$ vs control.

granulosa lutein cells increased compared with that in untreated control cultures (Fig. 5). The minimum concentration of AM required for a statistically significant increase in progesterone production was $10^{-8} \mathrm{~mol} / \mathrm{l}$, which was higher than the physiological concentration in the follicular fluid.

\section{Discussion}

It is well known that AM is produced by a variety of tissues and that it has diverse functions (7-11). High levels of AM have been found in human plasma, lung, adrenal gland, kidney and pancreas $(2,16,17)$. AM and its related peptide have been reported to influence the secretion rate of several hormones such as catecholamine (18), adrenocorticotropin (ACTH) (11), aldosterone (19), and insulin (17). It has been reported recently that AM might play a role in the differentiation of rat granulosa cells via an autocrine/paracrine mechanism (20).

We carried out this study to determine whether AM was expressed in human granulosa cells and to evaluate its possible role in the human ovary. When the concentrations of AM were measured in the follicular fluid and the plasma just before ovulation, the concentrations of AM were significantly higher in the follicular fluid than those in the plasma. This suggests either local secretion of AM into the follicular fluid or condensation of AM by the components in the ovarian follicle. To elucidate if AM can be synthesized in human granulosa cells, granulosa cells obtained at the time of oocyte retrieval were cultured in vitro in the presence of ${ }^{35}$ S-cysteine- ${ }^{35}$ S-methionine.

Since the granulosa cells were obtained from preovulatory follicles $36 \mathrm{~h}$ after the hCG injection of an IVF program, they seem to have been luteinized in vivo and seem to undergo further luteinization during the process of culture in vitro. This was evidenced by an increased secretion of progesterone by these cells. RTPCR with specific primers for AM using RNA obtained from granulosa cells just before ovulation, revealed the presence of AM mRNA in the mature granulosa cells. Furthermore, immunoprecipitation of the media with a specific antibody to AM, followed by electrophoresis on an SDS-PAGE demonstrated a band corresponding to ${ }^{35}$ S-labeled AM. This indicates that AM was synthesized and secreted by granulosa lutein cells. Consistently, immunohistochemical staining for AM showed that AM was most abundant in granulosa lutein cells at the midluteal phase, less abundant in granulosa cells in dominant follicles, and least abundant in granulosa cells in primordial and preantral follicles in the human ovary. These findings obtained in the present study are inconsistent with an earlier report by Abe et al. (20) who found that the maturation and luteinization of rat granulosa cells induced by gonadotropins were associated by a significant suppression in AM mRNA expression in those cells cultured in vitro. By contrast, in the present study with human ovaries, AM expression in granulosa cells became apparent in preovulatory follicles and was most abundant in granulosa lutein cells in the corpus luteum at the midluteal phase. The reason for the difference between our results and those of Abe et al. is not known. However, the apparent conflict of the data obtained by rat granulosa cells in vitro and human granulosa cells in vivo may be due to species differences or to differences in the environment in which granulosa cell specimens were obtained, that is, in vivo or in vitro.

Ovulation and the subsequent luteinization of granulosa cells in the ovulated follicle are associated with the expansion of local vascular lumen, increasing vascular permeability and angiogenesis (21). Since AM is known to be a strong vasodilator as well as an angiogenic factor (22), it seems likely that AM may play a role in the formation of the corpus luteum, particularly through involvement in the dynamic changes in vascular structure in the corpus luteum. Further studies will be needed to prove this and to resolve the conflict in human and rat data.

Regarding the possible participation of $\mathrm{AM}$ in the regulation of ovarian endocrine function, we noted that the addition of AM increased the production of progesterone by cultured granulosa lutein cells. Since it is now evident that AM is produced by granulosa lutein cells, AM seems likely to up-regulate progesterone production by granulosa lutein cells in an autocrine manner. The concentrations of AM required for the augmentation of progesterone production by cultured granulosa lutein cells were higher than physiological concentrations. The higher concentrations of AM required for increasing the progesterone production by human granulosa lutein cells in vitro were assumed to be needed for surpassing the effect of intrinsic AM. 
In conclusion, we have demonstrated for the first time that AM is transcribed and secreted by human granulosa lutein cells and that AM acts as a local factor to enhance progesterone production by granulosa lutein cells. Progesterone production by granulosa cells is regulated by a number of growth factors such as thyroid hormone $(23,24)$, insulin, insulin-like growth factor-I (25) and epidermal growth factor $(26,27)$. Thus, further studies on the interaction of AM with growth factors will be necessary for a better understanding of the biological relevance of $\mathrm{AM}$ in the regulation of human granulosa lutein cell function.

\section{Acknowledgements}

This work was supported in part by Grants in Aid for Scientific Research 10470346 from the Japanese Ministry of Education, Science and Culture and by the International Committee of the Population Council, New York, USA.

\section{References}

1 Kitamura K, Kangawa K, Kawamoto M, Ichiki Y, Nakamura S, Matsuo $\mathrm{H}$ et al. Adrenomedullin: a novel hypotensive peptide isolated from human pheochromocytoma. Biochemical and Biophysical Research Communications 1993192 553-560.

2 Ishimitsu T, Kojima M, Kangawa K, Hino J, Matsuoka H, Kitamura $\mathrm{K}$ et al. Genomic structure of human adrenomedullin gene. Biochemical and Biophysical Research Communications 1994 203 631-639.

3 Kitamura K, Sakata J, Kangawa K, Kojima M, Matsuo H \& Eto T. Cloning and characterization of cDNA encoding a precursor for human adrenomedullin. Biochemical and Biophysical Research Communications 1993194 720-725.

4 Washimine H, Kitamura K, Ichiki Y, Yamamoto Y, Kangawa K, Matsuo $\mathrm{H}$ et al. Immunoreactive proadrenomedullin N-terminal 20 peptide in human tissue, plasma and urine. Biochemical and Biophysical Research Communications 1994202 10811087.

5 Kitamura K, Kangawa K, Ishiyama Y, Washimine H, Ichiki Y, Kawamoto $\mathrm{M}$ et al. Identification and hypotensive activity of proadrenomedullin N-terminal 20 peptide (PAMP). FEBS Letters $199435135-37$.

6 Kuwasako K, Kitamura K, Ichiki Y, Kato J, Kangawa K, Matsuo H et al. Human proadrenomedullin N-terminal 20 peptide in pheochromocytoma and normal adrenal medulla. Biochemical and Biophysical Research Communications $1995211694-699$.

7 Kitamura K, Ichiki Y, Tanaka M, Kawamoto M, Emura J, Sakakibara $\mathrm{S}$ et al. Immunoreactive adrenomedullin in human plasma. FEBS Letters $1994341288-290$.

8 Ichiki Y, Kitamura K, Kangawa K, Kawamoto M, Matsuo H \& Eto T. Distribution and characterization of immunoreactive adrenomedullin in human tissue and plasma. FEBS Letters 1994338 6-10.

9 Ebara T, Miura K, Okumura M, Matsuura T, Kim S, Yukimura T et al Effect of adrenomedullin on renal hemodynamics and functions in dogs. European Journal of Pharmacology 1994263 69-73.

10 Yamaguchi T, Baba K, Doi Y \& Yano K. Effect of adrenomedullin on aldosterone secretion by dispersed rat adrenal zona glomerulosa cells. Life Sciences 199556 379-387.

11 Samson WK, Murphy T \& Schell DA. A novel vasoactive peptide, adrenomedullin, inhibits pituitary adrenocorticotropin release. Endocrinology $19951362349-2352$.
12 Ishiyama Y, Kitamura K, Ichiki Y, Nakamura S, Kida O, Kangawa K et al. Hemodynamic effects of a novel hypotensive peptide, human adrenomedullin, in rats. European Journal of Pharmacology 1993 $241271-273$.

13 Upton PD, Austin C, Taylor GM, Nandha KA, Clark AJL, Ghatei MA et al. Expression of adrenomedullin (ADM) and its binding sites in the rat uterus: increased number of binding sites and ADM messenger ribonucleic acid in 20-day pregnant rats compared with nonpregnant rats. Endocrinology 1997138 2508-2514.

14 Macri CJ, Martinez A, Moody TW, Gray KD, Miller M-J, Gallagher M et al. Detection of adrenomedullin, a hypotensive peptide, in amniotic fluid and fetal membranes. American Journal of Obstetrics and Gynecology 1996175 906-911.

15 Iorio R-D, Marinoni E, Scavo D, Letizia C \& Cosmi EV. Adrenomedullin in pregnancy. Lancet 1997349328.

16 Martinez A, Miller M-J, Unsworth EJ, Siegfried JM \& Cuttitta F. Expression of adrenomedullin in normal human lung and in pulmonary tumors. Endocrinology 1995136 4099-4105.

17 Martinez A, Weaver C, Lopez J, Bhathena SJ, Elsasser TH, Miller M-J et al. Regulation of insulin secretion and blood glucose metabolism by adrenomedullin. Endocrinology $19961372626-$ 2632.

18 Kato F, Kitamura K, Niina H, Yamamoto R, Washimine H, Kangawa $\mathrm{K}$ et al. Proadrenomedullin N-terminal 20 peptide (PAMP), an endogenous anticholinergic peptide: its exocytotic secretion and inhibition of catecholamine secretion in adrenal medulla. Journal of Neurochemistry 199564 459-461.

19 Yamaguchi T, Baba K, Doi Y \& Yano K. Effect of adrenomedullin on aldosterone secretion by dispersed rat adrenal zona glomerulosa cells. Life Sciences 199556 379-387.

20 Abe K, Minegishi T, Tano M, Hirakawa T, Tsuchiya M, Kangawa K et al. Expression and effect of adrenomedullin on rat granulosa cell. Endocrinology $19981395263-5266$.

21 Cavender JL \& Murdoch WJ. Morphological studies of the microcirculatory system of periovulatory ovine follicles. Biology of Reproduction 198839 989-997.

22 Zhao Y, Hague S, Manek S, Zhang L, Bicknell R \& Rees MCP. PCR display identifies tamoxifen induction of the novel angiogenic factor adrenomedullin by a non estrogenic mechanism in the human endometrium. Oncogene 199816 409-415.

23 Maruo T, Hayashi M, Matsuo H, Yamamoto T, Okada H \& Mochizuki M. The role of thyroid hormone as a biological amplifier of the actions of follicle stimulating hormone in the functional differentiation of cultured porcine granulosa cells. Endocrinology 1987121 1233-1241.

24 Maruo T, Hiramatsu S, Otani T, Hayashi M \& Mochizuki M. Increase in the expression of thyroid hormone receptors in porcine granulosa cells early in follicular maturation. Acta Endocrinologica $1992127152-160$.

25 Maruo T, Hayashi M, Matsuo H, Ueda Y, Morikawa H \& Mochizuki M. Comparison of the facilitative roles of insulin and insulin-like growth factor-I in the functional differentiation of granulosa cells: in vitro studies with the porcine model. Acta Endocrinologica 1988 117 230-240.

26 Maruo T, Ladines-Llave CA, Samoto T, Matsuo H, Manalo AS, Ito $\mathrm{H}$ et al. Expression of epidermal growth factor and its receptor in the human ovary during follicular growth and regression. Endocrinology 1993132 924-931.

27 Maruo T, Hiramatsu S, Matsuo H \& Mochizuki M. Dual action of epidermal growth factor on proliferative activity and differentiated function of granulosa cells during follicular maturation. In New Achievements in Research of Ovarian Function: Frontiers in Endocrinology, pp 81-87. Eds S Fujimoto, AJW Hsueh \& JF Strauss. Ares Serono Symposia, Via Ravenna, Italy 1995.

Received 28 September 1999

Accepted 9 February 2000 